\title{
BYZANTSKO-SLOVANSKÁ TRADÍCIA V STARŠOM OBDOBÍ VÝVINU SLOVENSKEJ KULTÚRY
}

\author{
The Byzantine-Slavic Tradition in the Older Period \\ of Slovak Culture Development
}

\author{
Peter Žeňuch
}

DOI: 10.17846/CL.2020.13.1.112-125

\begin{abstract}
EŇUCH, Peter. The Byzantine-Slavic Tradition in the Older Period of Slovak Culture Development. Byzantine culture began to develop in the Great Moravian environment on the Middle Danube and in Slovakia of that period of time. However, the beginning of its expansion is associated not only with the southern and eastern Slavs, where through the Wallachian colonization the Church Slavonic language, liturgy, religiosity and spirituality spread to Slovakia. The important centre of the Byzantine culture was Vyšehrad [hung. Visegrád] on the Danube, especially during the 11th - 13th century, where the Greek liturgy existed. The autochthonous Slovak ethnic group in connection with the application of the Wallachian economic system was also significantly involved in the process of its revival in Slovakia. Evidence of this process is petrified in the language of the Slovak community. It is the language, as a representative of cultural and national identity that preserves all important and historically verifiable cultural-communication traces in its system. The present study thus provides a picture of the earlier period of the development of the Slovak language in relation to the Byzantine-Slavic tradition as a forming component of Slovak national culture.
\end{abstract}

Keywords: Byzantine-Slavic tradition; Church Slavonic language; Cyrillic written sources; linguistic, cultural and confessional identity

\begin{abstract}
Abstrakt: ŽEŇUCH, Peter. Byzantsko-slovanská tradícia v staršom období vývinu slovenskej kultúry. Byzantská kultúra sa začala rozvíjat vo vel'komoravskom prostredí na strednom Dunaji a na vtedajšom Slovensku. Začiatok jej rozmachu sa však spája nielen s južnými a východnými Slovanmi, odkial sa prostredníctvom valašskej kolonizácie cirkevnoslovanský jazyk, liturgia, religiozita a duchovnost' rozšírila aj na Slovensku. Významným centrom byzantskej kultúry bol Vyšehrad na Dunaji, najmä počas 11.-13.storočia, kde existovala grécka liturgia.. Do procesov jej opätovného oživenia na Slovensku sa významne zapojilo aj autochtónne slovenské etnikum $\mathrm{v}$ spojení s uplatňovaním valašského hospodárskeho systému. Dôkazy o tomto procese sú petrifikované $\mathrm{v}$ jazyku slovenského spoločenstva. Práve jazyk ako reprezentant kultúrnej a národnej identity uchováva vo svojom systéme všetky významné a historicky verifikovatelné kultúrno-komunikačné stopy. Predstavovaná štúdia tak poskytuje obraz skoršieho obdobia vývinu slovenského jazyka vo vztahu k byzantsko-slovanskej tradícii ako formujúceho komponentu slovenskej národnej kultúry.
\end{abstract}

Klúčové slová: byzantsko-slovanská tradícia, cirkevná slovančina; cyrilské písomné pramene; jazyková, kultúrna a konfesionálna identita 
Výskum vztahov slovenského jazyka so slovanskými i neslovanskými jazykmi pomáha pri odkrývaní obrazu o plynulom, kontinuálnom a systematickom vývine slovenskej spoločnosti aj v rámci interkultúrnej a interkonfesionálnej komunikácie. Jazyková, kultúrna, spoločenská i štátnopolitická identita slovenského etnika sa naplno realizovala už od najstaršieho obdobia praslovanského vývinu slovanských etník, o čom svedčia rozličné písomné pramene i celý rad dokladov materiálnej kultúry. Jednotlivé písomné pramene i pamiatky materiálnej kultúry dokumentujú duchovné a kultúrne dedičstvo Slovákov od čias Vel'kej Moravy, ktorá bola spätá s krestanskou cirkvou latinského i byzantského obradu. Slovenské etnikum sa ako významný aktívny element zapojilo aj do formovania uhorskej štátnosti a pôsobilo tiež ako aktívny činitel’ v kultúrnych procesoch spätých s uplatňovaním nemeckého i valašského hospodárskeho systému. Aj slavistický jazykovedný výskum prináša $\mathrm{v}$ tomto rámci poznatky, ktoré sú potrebné pre komplexné poznanie historicko-kultúrneho vývinu slovenskej spoločnosti a o jej zapojení sa aj do jednotlivých foriem hospodárskeho systému nemeckého či valašského práva. Tieto skutočnosti poskytuje práve porovnávací jazykovedný diachrónny výskum jazyka prameňov písomnej kultúry, ktoré dokumentujú reálie z každodenného života Slovákov spätých s prostredím rurálnej i mestskej spoločnosti.

Významnú zložku týchto písomných prameňov predstavujú rozličné jazykové prostriedky, ktoré tvoria systémovú zložku slovenčiny podnes, ale tiež rozličné lexikálne prostriedky a terminológia z oblasti polnohospodárstva, remeselníctva, tiež terminológia administratívnej a právnej povahy. Práve terminológia poukazuje na spoločenský, kultúrny, hospodársky i cirkevný život na Slovensku. Slovná zásoba pritom predstavuje dôležitý doklad o stupni spoločenského, hospodárskeho i kultúrneho rozvoja a je obrazom každodenného života spoločnosti (Pauliny 1965, 190203; Pauliny 1961, 5-39). Jednotlivé vývinové stupne historického rozvoja slovenčiny a slovenskej kultúry v jednotlivých regiónoch a oblastiach Slovenska odrážajú nárečia, ktoré sú integrálnou zložku slovenského národného jazyka. Pre jazykovedca i historiografa je tak poznanie vývinu slovnej zásoby a jeho systémových fonetických i morfologických javov dôležitým zdrojom poznávania kontinuálneho kultúrneho myslenia nositelov slovenskej identity. Práve v jazyku ako nástroji komunikácie a myslenia sa uchováva, petrifikuje obraz o dôležitých a historicky verifikovatelných udalostiach spoločenského, konfesionálneho a kultúrneho života jeho nositelov a používatelov. Jazyk je trvalou, platnou a udržatel'nou hodnotou, je neoddelitel'nou súčastou historického vedomia a znakom konvergentného, spoločného myslenia o dejinách, kultúre a spoločnosti a tiež o blízkych i vzdialených susedoch. Jazyk je kontinuálnym reprezentantom identity celku, ktorým sa etnikum vymedzuje navonok i do vnútra spoločenstva v každej jednej etape svojho kultúrnohistorického vývinu (Žeňuch 2013a, 11-30).

Osobitnú skupinu písomných prameňov tvoria také cyrilské i latinské písomné pramene byzantskej tradície, na základe ktorých sa už podarilo poukázat na významný podiel Slovákov pri kultúrno-identifikačných procesoch byzantskej cirkvi slovanského obradu pod Karpatmi (Žeňuch 2008, 97-107; Žeňuch 2015; Žeňuch 2017, 21-36; Žeňuch 2019). V týchto písomnostiach možno totiž na základe jazykových prostriedkov už od najstaršieho obdobia vývinu slovenskej kultúry dokumentovat jazykový i religiózny rozmer identity slovenského obyvatel'stva, ktoré je späté s latinským i s byzantsko-slovanským konfesionálnym prostredím. ${ }^{1}$ Byzantský obrad

Latinské i grécke prevzatia svedčia o synkretizme jazykových a kultúrnych vplyvov, ktoré na Velkej Morave pôsobili, napríklad paralelné používanie lexém omša popri služba, križ popri krest, dảej jerej, pop i kñaz na označovanie duchovného stavu či uplatňovanie lexémy oltár na označenie obetného stola spolu s významom, ktorým sa označuje priestor, kde sa obetný stôl nachádza, a pod. Práve vel'komoravská staroslovienčina je zdrojom poznatkov o rozvoji najstaršieho slovanského kultúrneho (v dnešnom ponímaní spisovného) jazyka. Túto terminológiu tvorí aj súbor lexém poznačených vplyvom krestanských misií z obdobia pred príchodom svätého Cyrila a Metoda do stredodunajského priestoru a pred konštituovaním 
a cirkevná slovančina ako liturgický jazyk a jazyk písomnej kultúry tvorí integrálnu súčast’ slovenského jazykovo-kultúrneho povedomia. Najviac dokladov tohto charakteru nachádzame podnes v živých východoslovenských nárečiach v Spišskej, Šarišskej, Užskej, Abovskej, Zemplínskej stolice, ale aj v nárečí obyvatelov Berežskej a Marmarošskej stolice. V tomto regióne, pravda, okrem Slovákov žijú aj rusínski a ukrajinskí veriaci cirkvi byzantsko-slovanského obradu, ale aj rómski, mad’arskí, rumunskí i pol’skí príslušníci tejto cirkvi.

Z cirkevnoprávneho hladiska tieto regióny tvorili integrálnu súčast' územia spadajúceho do jurisdikcie mukačevského biskupa vykonávajúceho práva obradového vikára ako sufragána jágerského latinského biskupa. Mukačevská cirkev si však aj napriek tejto podriadenosti latinskému jágerskému biskupovi zachovala svoju ekleziálnu identitu nielen vo vztahu k latinskej cirkvi v Uhorsku, ale aj vo vztahu k ostatným cirkvám byzantského obradu na Ukrajine, v Moldavsku a pod. (Zubko 2016, 3-9). Veriacich byzantského obradu v karpatskom priestore totiž spája najmä spoločný kultúrny a historický vývin Uhorska, v ktorom sa sformovala aj kultúrna a ekleziálna identita byzantsko-slovanskej tradície pod Karpatmi a na Slovensku (Žeňuch 2014, 121-137; Žeňuch 2016, 10-32).

Miloš Marek $(2006,253)$ v súvislosti s valašskou kolonizáciou v západných Karpatoch a na Slovensku uvádza, že kým na území Sedmohradska dominoval rumunský etnický element, $\mathrm{v}$ severovýchodných Karpatoch prebral štafetu živel rusínsky a s jeho postupom na západ sa na tomto procese čoraz výraznejšie podielala domáca autochtónna slovenská zložka, pričom východoslovanské etnikum v priebehu 14. - 16. storočia utvorilo na východnom Slovensku svoju sídliskovú základňu, ktorá sa takmer v nezmenenej podobe udržala podnes. ${ }^{2}$

Fakt, že slovenské autochtónne obyvatel'stvo sa zapojilo do kolonizačného procesu spätého $s$ valašským hospodárskym prostredím, ktoré bolo pevne spojené s byzantsko-slovanskou liturgickou tradíciou, možno doložit aj v pomenovaniach ruského (východoslovanského) etnika, ktoré na Slovensko prichádzalo spoza Karpát od 14. storočia ako valašský pastiersky element. Významová motivácia pomenovania rusnák má však okrem etnického aj konfesionálny rozmer.

Pomenovanie Rusnák predstavuje západoslovanskú podobu etnonyma spätého s východoslovanským etnickým a jazykovým prostredím. Na jeho západoslovanskú podobu poukazuje prípona -ák. Táto prípona sa začala hojnejšie využívat pri tvorbe etnoným a obyvatelských mien v západoslovanskom a slovenskom jazykovom prostredí (Gerovskiy 1957, 429-442), kde nakoniec ako slovotvorná prípona obyvatel'ských mien aj prevážila. Svedčia o tom západoslovanské tvary používané

velkomoravskej cirkvi, napr.: kňaz (кнАзь), рор (попъ) і popad’a (попадА), mních, mníška (мънихъ, мънишица), kaluger (калжгеръ), služba (служба) рорri omša (мьша), večerňa (вечернА), роvečerňa (повечерна), masopust (мАсопжстъ), ceta (цАта; vo význame ,drobná minca'), čelad' (челАдь), komkanie (комканї), ocot (шцътъ), igumen (игжменъ), imanie (иманї), archijerej (архиерей), prosfora (просфжра) a d’alšie. Takáto terminológia je jedinečným dokladom o prepojení najstaršieho horizontu slovanskej a velkomoravskej duchovnej kultúry s jej pokračovaním v slovanských cirkvách byzantského obradu. Vývin slovnej zásoby jazyka je dokumentom o rozvoji spoločnosti. Slovná zásoba obsahuje terminológiu zahrnujúcu rozličné oblasti hospodárskeho, spoločenského i kultúrneho života, obsahuje pomenovania rozličných remesiel a činností, administratívnu, náboženskú, právnu terminológiu. Zachováva tak priame historické doklady o existencii zjednocujúceho krestanského spoločenského i kultúrneho dedičstva, ktoré sa bez prerušenia, kontinuitne formuje od čias našich predkov (Žeňuch - Belyakova - Naydenova Zubko - Marinčák 2018, 24-25). Synergia duchovných zdrojov obradovo latinskej i byzantsko-slovanskej kultúrnej a religióznej tradície zohrala rozhodujúcu úlohu aj pri formovaní slovanského písomníctva a kultúry. Túto synergiu potvrdzujú mnohé známe i menej známe pramene (pozri Olteanu 1947, Mareš 1979, Stanislav 1978, Žeňuch 2013b a pod.)

2 Hranicu medzi slovenskými a rusínskymi etnickými a jazykovými spoločenstvami dobre opísal Samo Cambel (Czambel 1906) a Ján Húsek (1925). 
na označenie etník ako Slovák, Poliak i dalšie názvy ako Soták, Lipták, Slezák, Serbak (odvodené od pomenovania Srb, východoslov. Serb), Prušiak, Záhorák, Dolniak, Horñák, tiež pomenovania Spišiak popri Spišan, Pražák popri Pražan, Moravák popri Moravan, Rusák, Prusák a i.

Aj etnonymum Slovák/Slovjak vzniklo tým, že sa k najstaršiemu slovotvornému kmeňu Slov- pridala prípona -ak/-iak, ktorá ako alternatívna prípona nahradila pôvodný sufix -en-, resp. -ěn-, alebo jej variant -jan- (Dorula 1993). Termín Sloviak (Slovjak) je tak iba východoslovenskou nárečovou obmenou etnonyma Slovák a nemá žiadnu inú etnickú motiváciu. Už Ján Stanislav $(1950,8)$ v tejto súvislosti uviedol mnohé doklady o tvorbe vlastných mien, ktoré zachovávajú párovú spoluhláskovú mäkkostnú koreláciu a sú podnes živé nielen v okruhu východoslovenských nárečí, ale aj v ostatnom slovenskom etnickom a jazykovom priestore, napr. Noviak, Suroviak, patria sem aj tvary Skybjak, Babjak, Hutorjak, Starjak, Dzuriak a dalšie (Žeňuch 2014, 127-129).

V lexéme Sloviak/Slovjak sa uplatňuje zmäkčený konsonant $v$ ', ktorý v rámci mäkkostnej korelácie tvorí pár s nezmäkčenou spoluhláskou $v$. Práve mäkkostná korelácia b-b’; p-p'; m-m'; v-v’ sa spolu s mäkkými spoluhláskami š a ž uplatňuje vo východoslovenských nárečiach až podnes. Osobitne výrazne sa uvedená mäkkostná korelácia zachovala v sotáckej a užskej jazykovej oblasti, kde sa pomenovanie slovenskej etnicity aj dnes vyjadruje termínom Slovjak. Dokazuje to napríklad cyrilský historický spis Dejiny novozákonnej cirkvi uložený v knižnici Užhorodskej národnej univerzity, ktorého autorom je mukačevský cirkevný historik z 18. storočia Michal Bradač, ktorý na pomenovanie Slovákov používa termíny Товты, Славы, ale tiež Слав^не і Слов^ки (Žeňuch 2014, 128-129). Okrem toho Michal Bradač vo svojom spise o Dejinách novozákonnej cirkvi uvádza: „Ижє намъ днєсъ нарицаю[тъ] сл Ршссїанє, ПолАки, Моравы, Чєхи или Богєми, ТовтыСлавы, албо Словнки, Болгари, Іллйры, Хорваты, Рацы, Сєрбы, Далматы и проч. вси єдинагш плємєнє соу[тъ]: что ғзыкъ вси[мъ] єди[нъ] ғзыкъ, нвствує[тъ] и Історїографы

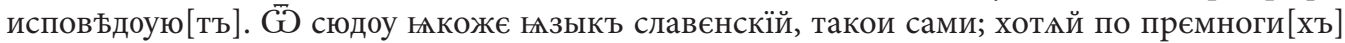
мїра страна[хъ] ршссїлны, со разными народами смишаны, и разлъчны[мъ] благочєстїє[мъ] владъємы соу[тъ], єдини[мъ] слово[мъ] Слав^не имєноуютъ сл. Моравы, или Моуравы (Latinis dicti Mara[c]henses) [...] знатны[хъ] КнАзєй или Королєвъ имили: Моймира (нєгли Коцєл^), Растїслава и С[в] Атополка (Моymarum, Rasticem, et Sviatoplugum) подъ которими и многш прославишасл. Разрушенїл крђпкаго царства своєго подлли $\bar{w}$ Оугровъ во началь

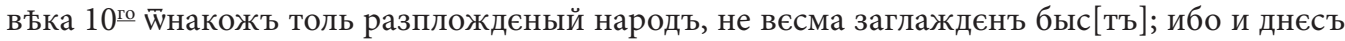
вєликоую частъ оугорскаго царства дєржи[тъ] во столицє Пожонской или Прєшбурской, Нїтранской, Трєнчанской, Турчанской, Оравской, Лїптовской и ины[хъ] по вышнєй Оугрїи вєлїимъ число[мъ] шбътающъ. Сей єдинъ и[зъ] славєнски[хъ] народшвъ имА СлавАновъ бєз[ъ] всАкаго прилога содєржи[тъ], и сєбє Словжками называєтъ“ (kurzíva P. Ž., porovnaj Žeňuch 2013b, 107-114).

Obyvatelia Vel'kej Moravy sami seba nazývali Словънє; singulatívna podoba tohto kolektívneho etnonyma је Словънинъ. Toto pomenovanie je utvorené pomocou prípony -инъ k základu Словън-. Takým istým spôsobom vzniklo aj pomenovanie obyvatelov Polska v tvare Полянинъ, pre obyvatelov bulharského cárstva sa používalo označenie Болгаринъ. Na označenie obyvatelov Kyjevskej Rusi sa v najstaršom období vývinu slovanských jazykov uplatnilo pomenovanie Русинъ, ktoré tiež vzniklo pomocou prípony -инъ deriváciou od slova Русь a predstavuje kolektívne etnonymum pre obyvatel'stvo žijúce $\mathrm{v}$ hraniciach tohto ranofeudálneho štátu vo východoslovanskom priestore. Pomenovaním Русинъ sa v najstarších historických dokladoch označuje obyvatel'stvo staroruského pôvodu. ${ }^{3}$ Pre obyvatel’ov Uhorska sa v slovanských jazykoch tohto obdobia uplatnilo pomenovanie Угринъ, ktoré vzniklo sufixáciou (pomocou prípony -in) z kolektívneho

\footnotetext{
V latinských písomnostiach sa pre nich ustálil termín Ruthenus.
} 
pomenovania obyvatel'stva Uhorska, ktoré bolo síce rozličnej etnickej a jazykovej príslušnosti, ale patrilo do jedného spoločného štátnopolitického priestoru. ${ }^{4}$

Aj pomenovaním Русинъ sa označovala príslušnost’ k štátnopolitického celku (Kyjevskej) Rusi, no toto pomenovanie sa používalo aj pre nositela východoslovanského jazyka. Pomenovanie Рyсuнъ (Rusín) je spoločné pomenovanie pre všetkých príslušníkov pochádzajúcich zo staroruského jazykového prostredia (Chuchka 1993, 121-128). $\mathrm{V}$ rovnakom tvare sa toto pomenovanie podnes používa na Slovensku na označenie členov etník východoslovanského pôvodu (najmä v kontaktných nárečových oblastiach východného Slovenska) za hranicami karpatského oblúka. V živej ludovej reči sa vo východoslovenskom nárečovom prostredí takto podnes označujú obyvatelia dnešnej Ukrajiny, Ruska i Bieloruska (Žeňuch 2014, 129). ${ }^{6}$

Na Slovensku, kde sa slovenské autochtónne obyvatel'stvo už od 14. - 15. storočia identifikovalo so svojím západoslovanským tvarom etnonyma Slovák, na označenie etnika východoslovanského pôvodu si utvorilo analogické pomenovanie Rusnak (Руснакъ). Pomenovanie Rusnak, resp. Rusňak začalo v prostredí etnicky ruskej kolonizácie na valašskom práve prevládat natol'ko, že si ho prisvojili aj členovia tohto pastierskeho spôsobu života. Pod priamym vplyvom slovenčiny sa pomenovanie Rusnak začalo používat' nielen ako etnonymum na označenie pastierskeho jazykovo východoslovanského elementu, ale aj na označenie spoločenstiev, ktoré sa prihlásili k byzantsko-slovanskej cirkvi, kedže táto tradícia bola typická pre valašský pastiersky kolonizačný element.

V 17. - 18. storočí do prostredia západných Karpát prišli dalǎśi presídlenci z Haliče, ktorí sami seba označovali pôvodným etnickým pomenovaním Rusín (Pусuнz) (Chuchka 1993). Jazyk týchto presídlencov z Haliče sa vo svojom základe ničím neodlišoval od jazyka valašského pastierskeho živlu z prvej vlny kolonizácie. Ide o jazyk, ktorý patrí do ukrajinského jazykového areálu a vo svojej podstate zachováva nielen typické starobylé vývinové jazykové zmeny, ktoré sú vo všetkých východoslovanských jazykoch rovnaké, ale zároveň sa nimi odlišuje od západoslovanskej skupiny jazykov. Tento jazykový útvar však nijako nemožno spojit’ s niektorým zo slovenských nárečí vo východoslovenskom jazykovom priestore, od ktorého sa jasne odlišuje napríklad tzv. „polnoglasie“ (-oro-, -olo-, -ere-; rus. a ukr. город, молоко, голова, дерево, берег; bielorus. горад, малако), d’alej sú to napríklad spoluhlásky č a ž na miestach, kde sa v západoslovanských jazykoch vyskytuje c a z/dz za pôvodné ${ }^{\star} t j$, ${ }^{\star}$ dj (napr. rus. свечa, ukr. свіча, bielorus. свяча - slov. svieca; rus. межа, печь - slov. medza, pec, čes. mez, pec), d’alej je to dôsledné používanie epentetického l' po perných spoluhláskach v spojení s j (napr. bj, pj, mj, vj, porov. rus., ukr., blr. земля, slov. zem, čes. země, pol.

4 Svedčí o tom prímeno kyjevsko-pečerského mnícha Mojžiša Uhorského, ktorého pôvod treba vidiet v Uhorsku. Pravdepodobne pochádzal z významného staroslovenského rodu a pohyboval sa v blízkom okruhu kyjevského kniežacieho dvora, ktorý tvorili urodzení predstavitelia domácej šlachty a honorabilita zo spriatelených krajín, ku ktorej Mojžiš Uhorský istotne patril. Zároveň bol jedným z predstavitelov a zakladatelov mnišskeho života podla studitskej reguly v Kyjevskej Rusi, čo umožňuje predpokladat toto jeho vysoké spoločenské postavenie (Bugan 2009, 137-146).

5 P. Čučka (Chuchka 1993) v tejto súvislosti poznamenáva, že v tomto pomenovaní sa okrem štátnopolitickej príslušnosti vyjadrovala aj etnická identita.

6 Možno to dokumentovat na príklade z každodennej jazykovej situácie, ked’ Slováci tzv. podomových obchodníkov prichádzajúcich z Ukrajiny s lacným tovarom volajú Rusin, Rusinka, napr.: „Prišla do nas (do valala) Rusinka z Ukrajiny, ta mi od nej kupila dvoji punčochi, “ alebo „Rusinka z Ukrajiny na pijacu predavala tote lachi za paru korunki“ a iné.

7 V prípade východoslovanského slova селезёнка (slov. slezina, čes. slinivka) treba vediet’ o praslovanskej podobe ${ }^{*}$ selezen , hoci existuje aj iný názor, že toto slovo vzniklo z psl. * ${ }^{*} e l z e n v$. Treba však vziat do úvahy najmä existenciu cirkevnoslovanského tvaru слюзена, starogréckej podoby $\sigma \pi \lambda \eta \dot{v}$ a tiež latinskej lexémy lien. Bližšie vysvetlenie k tomu ponúka André Vaillant (1960, 66-67). V prípade ruského tvaru slova жёлоб, желобо́к (slov. žlab, žliabok) sa napriek vonkajšej podobnosti rovnako nedokladuje „polnoglasie“. 
ziemia). Patrí sem aj osobitný vývin spoluhláskovej skupiny kv-, gv- na začiatku slova pred в (slov. kvet, hviezda), z ktorých vo východoslovanských jazykoch vznikli spoluhláskové skupiny cv-, zv(rus. цвет, звезда; ukr. цвіт, звізда). Rovnako sem patrí aj zjednodušenie spoluhláskovej skupiny -dl-, -tl- na -l-, ktorá je spoločná pre celý východoslovanský jazykový areál (мыло, сало, плела oproti slov. mydlo, sadlo, plietla) a dalšie (porovnaj k tomu Žeňuch 2018, 75-85). Túto skutočnost' treba osobitne podčiarknut aj vzhladom na viaceré práce, ktoré prezentujú nesystémový obraz o formovaní východoslovenského jazykového kontextu (Charskiy 2011).

Treba však zdôraznit' aj dalšiu skutočnost', že toto pôvodne východoslovanské (ruské) obyvatel'stvo netvorí na Slovensku územne kompaktné prostredie, lebo dediny a osady s týmto ruským obyvatel'stvom tvorilo aj autochtónne slovenské obyvatel'stvo, s ktorým sa tento pastiersky živel miešal, splýval, alebo prevládal. Podnes známe rusínske oblasti v celej dľžke Karpát neboli a podnes nie sú jazykovo jednoliate.

Pojem rusnak má tiež silný sociálny aspekt (Plišková 2009). Táto skutočnost’ sa dokonca spomína aj v úvode ku Kocakovej gramatike z roku 1788: дабы і насъ мпззерных Руснаковъ не судили всп аки спростаковъ. Vo všeobecnosti možno uviest' skutočnost', že sociálne postavenie, či akýsi status dnešných Rusínov sa vo vedomí obyvatel'stva na Slovensku spája so stereotypom založenom na akejsi kultúrno-obradovej rivalite (Šoltés - Žeňuch 2001, 133-146, Šoltés - Žeňuch 2002, 37-47; Šoltés 2009). Podnes sa aj preto v tomto kontexte stereotypne stotožňuje pojem gréckokatolík s pojmom rusnak a v praxi sa tieto termíny prirodzene a plnohodnotne zamieňajú a používajú ako synonymá, čo umožňuje označovat' za príslušníka východoslovanského jazykového prostredia všetkých veriacich cirkvi byzantsko-slovanského obradu bez rozdielu ich jazykovej identifikácie.

Hoci byzantská konfesionálna tradícia má svoje pokračovanie predovšetkým medzi južnými a východnými Slovanmi, kde sa naplno uplatnila a kde vznikla aj bohatá slovanská písomná kultúra. Slovanský religiózny rozmer tejto tradície sa udržal na Vyšehrade pri Dunaji až do jeho odovzdania latinským mníchom začiatkom 13. storočia (Avenarius 1992, 113-132). Prostredníctvom kolonizácie na valašskom práve sa posilnil v slovenskom jazykovom a kultúrnohistorickom prostredí (Žeňuch 2015, 21). Dokumentuje to práve jazyk liturgie a bohoslužobných obradov slávených v cirkevnej slovančine spolu s duchovnou a religióznou tradíciou veriacich. Táto duchovná a religiózna tradícia sa prejavuje v celom rade cirkevných pravidiel, na ktoré sme poukázali už pri vydaní Užhorodského rukopisného Pseudozonara, v ktorom sa nachádzajú jazykové javy súvisiace s vel'komoravským jazykovým prostredím. J. Vašica $(1996,72-92)$ totiž predpokladá, že Metodovo dielo cirkevnoprávneho charakteru mohlo bezprostredne ovplyvnit aj vznik dalších textov právneho charakteru a tiež ich výklady, ktoré vznikli v južnoslovanskom prostredí, odkial' sa rozšírili do celého slovanského sveta, kde sa ujala a rozvíjala byzantská cirkev slovanskej tradície. Texty výkladov jednotlivých pravidiel či kánonov sú preto významným historicko-právnym prameňom, ktorý nemožno vnímat oddelene od historicko-spoločenských reálií, v ktorých sa uplatňovali, a ani od ostatných podobných zborníkov či súborov kánonických textov a pravidiel svetského a cirkevného života, z ktorých v prostredí slovanskej cirkvi byzantského obradu aj čerpali. Práve zborníky pravidiel, ktoré vznikali pre potreby miestnej cirkvi, poukazujú na prepojenie duchovného (religiózneho) života s každodennostou jednoduchého človeka. Popri návodoch pre veriaci lud tvoria osobitnú čast' zborníkov s pravidlami určenými pre miestnu komunitu veriacich aj zásady pre život $\mathrm{v}$ mníšskom prostredí i pre biskupov miestnej cirkvi. Pravidlá svetského a cirkevného života a ich výklady, epitimiové pravidlá a penitenciál predstavujú dôležitý dokument, ktorý opisuje vztahy medzi svetskými i duchovnými stavmi spoločnosti (Jáger 2018, 67-77; Jáger 2019, 115-120). Používanie ustálenej právnej terminológie je pritom základným prejavom identity najstaršej podoby krestanského cirkevného práva u Slovanov, s čím súvisí práve základný princíp využitel’nosti právnej normy je jej publicita a všeobecná zrozumitel’nost'. Právne normy a predpisy preto predstavujú vnútorne koncízny a širokému spektru používatelov zrozumitelný 
celok, pričom efektívnost pravidiel a kánonov závisí od jazyka a štýlu (Považan 2014, 18-25), ktorým sa tieto právne zásady zapisujú a vykladajú. ${ }^{8}$

Aj do kontextu duchovnej kultúry prenikali mnohé osobitosti späté s prostredím byzantského obradu. Platí to osobitne aj v súvislosti so slávením sviatku sv. Demetra Solúnskeho a s vysväcovaním chrámov zasvätených tomuto svätcovi. P. Labanc $(2017,207)$ v tomto kontexte uvádza, že sviatok mal síce na Spiši svoje miesto a „bol zaradený aj do kalendárií, ktoré sa v tejto cirkevnej ustanovizni používali. A vskutku sa jeho slávenie, na rozdiel od západnej Európy, na Spiši uvádza 8., resp. 26. októbra. (...) Jesenný termín však nie je spišským špecifikom, ale všeobecným uhorským zvykom. V každom prípade slávenie sviatku nemožno v Spišskej kapitule považovat za výnimočné, presahujúce rámec ostatných celocirkevných sviatkov (v kalendáriu bol totiž zapísaný bežným čiernym atramentom), a preto je uvažovanie nad jeho spišskou tradíciou od čias cyrilo-metodskej misie bezpredmetné." P. Labanc sa síce odvoláva na štúdiu M. Neumanna (2014, 8-32), no nevšíma si už jeho konštatovanie o tom, že šírenie kultu sv. Demetra a dalších sviatkov súvisiacich s cyrilo-metodským dedičstvom, nie je iba výsledkom oživovacích procesov tejto tradície, ktoré sa šírili z českého prostredia z pražského emauzského kláštora či olomouckého biskupstva. Tu treba zdôraznit, že česká Kozmasova kronika zachytáva starobylú legendu o Svätoplukovi a zoborskom kláštore, ktorú autor tejto kroniky zapísal práve počas svojho pobytu $\mathrm{v}$ tejto časti Uhorska. Vidiet’ v nej práve kontinuum o živom historickom povedomí Slovákov pretrvávajúcom z vel'komoravského obdobia. Oživovanie vel'komoravskej tradície, ako ho spomína P. Labanc, prenikalo do Uhorska a na Slovensko práve v období, ked’ sa v Európe šírili predstavy o bulharsko-ruskom pôvode byzantskej vzdelanosti v slovanskom kontexte. Latinský západ byzantsko-slovanskú cirkev po rozkole (1056) však pokladal za heretickú, sektársku, a to najmä pre jazyk liturgických obradov. Táto nevraživost’ voči byzantsko-slovanskej bohoslužobnej tradícii začala v latinskej cirkvi v Uhorsku silniet práve v období, ked’ sa aj do slovenského prostredia šírila valašská kolonizácia $\mathrm{z}$ východoslovanského (rus'kého) prostredia. O neprajnosti latinskej kultúry voči slovanskej tradícii v prostredí byzantskej cirkvi svedčí aj Dalimilovo označenie Metoda za Rusína (Ten arcibiskup Rusín bieše, mši slovensky slúžieše, ktoré poznáme z jeho kroniky), ktoré dobre dokumentuje religióznu a obradovo byzantsko-slovanskú identitu kultúrneho povedomia. V Dlugošovej kronike z 15. storočia sa $\mathrm{v}$ podobnom duchu uvádzajú skutočnosti o počiatkoch slovanskej vzdelanosti a cyrilo-metodskom účinkovaní (Žeňuch 2015, 22-23). Treba však vziat' do úvahy reálie, na ktoré poukazuje jazykoveda. Napríklad J. Dorula (2012, 19, 85-86) vysvetluje skutočnosti späté s hospodárskym a kultúrnym životom valašskej pastiersko-ovčiarskej kolonizácie v horských oblastiach Slovenska v spojení s pôvodným slovenským obyvatelstvom, ktoré tak prišlo do priameho živého kontaktu s ukrajinským etnickým živlom. Tento živel sa postupne zlieval s domácim slovenským obyvatel'stvom, spoločensky, kultúrne i jazykovo sa asimiloval v slovenskom prostredí. O prítomnosti ukrajinského etnického živlu, ktorý sa tradične spája s byzantským obradom, máme v slovenských písomnostiach mnoho dokladov.

Cirkevná slovančina, ktorú používajú podnes slovenskí veriaci pri bohoslužbách byzantského obradu, obsahuje znaky živej ludovej reči slovenských veriacich. Na základe našich dlhoročných výskumov slovenských gréckokatolíkov sa totiž ukázalo, že východoslovanský variant cirkevnej slovančiny je v slovenskom prostredí ovplyvnený jazykovým povedomím slovenských veriacich, teda používatelov spišského, zemplínskeho, šarišského, užského, sotáckeho nárečia (Žeňuch 2000, 231-274; Žeňuch 2011, 51-62; Žeňuch 2017, 21-36). Slovanskí používatelia liturgického jazyka v rámci obradov svojej cirkvi byzantského obradu uplatňujú takú podobu liturgického jazyka, ktorá odráža ich jazykové povedomie. Na Slovensku sa tak používajú dva varianty liturgického

8 K problematike terminológie velkomoravského pôvodu v najstarších i neskorších prameňoch byzantskej cirkvi slovanskej tradície sa venuje nemalá pozornost' (Afanas'eva 2012; Krivko 2015; Maksimovich 2007). 
cirkevnoslovanského jazyka: slovenský a podkarpatskoruský variant. Tieto varianty cirkevnoslovanského liturgického jazyka sú výsledkom prirodzeného jazykového vývinu jeho používatelov. Používanie cirkevnej slovančiny ako liturgického jazyka v slovenskom jazykovom prostredí je neoddelitelnou súčastou jazykovo-kultúrnej identity slovenských veriacich byzantsko-slovanského obradu. Liturgický cirkevnoslovanský jazyk je vo svojej štruktúre priamym pokračovatelom staroslovienčiny, najstaršieho slovanského liturgického a literárneho jazyka Slovanov z velkomoravského obdobia, a tak aj cirkevnú slovančinu ako liturgický jazyk nemožno pokladat za reprezentanta jedného jazykového spoločenstva. Jej pôvod je v južnoslovanskom jazykovom prostredí, kde sa aj po páde Vel'kej Moravy rozvinula táto cirkevnoslovanská liturgická i písomná kultúra a odkial' sa rozšírila k východným Slovanom. Prostredníctvom valašskej kolonizácie sa byzantská liturgia, slovanský liturgický jazyk, religiozita či duchovnost’ opätovne dostala do slovenského prostredia. Slovenské obyvatel'stvo takým spôsobom prirodzene splynulo s byzantsko-slovanským religióznym prostredím a postupne sa stalo aj jeho formujúcim a v mnohých kontextoch aj prevažujúcim elementom na Slovensku (Žeňuch 2015; Žeňuch 2019, 51-60).

Svedčia o tom práve písomne pramene, ktoré z formálnej stránky sú síce napísané cyrilikou, pričom existenciu slovenských veriacich dosvedčujú práve prostredníctvom reálií i jazykových znakov v textoch cyrilskej duchovnej písomnej kultúry, ktorá sa prispôsobovala potrebám a jazykovému povedomiu slovenských používatelov. Napriek tomu však na Slovensku samostatná redakcia cirkevnej slovančiny nevznikla. Významnú rolu v kultúrnom živote veriacich byzantského obradu však predstavovala aj latinčina, ktorá bola v Uhorsku ústredným jazykom svetskej i cirkevnej správy, kroník, vzdelaneckej spisby. Prostredníctvom ustálenej latinskej administratívnoprávnej terminológie prenikala aj do cyrilskej písomnej kultúry (Zubko 2019, 30-45; Wilšinská 2019, 125-133; Zavarský 2019, 113-124; Strýčková 2019, 134-144). Dokazujú to nielen texty napísané po latinsky, ale aj mnohé prevzatia $\mathrm{z}$ latinčiny. Latinčina $\mathrm{v}$ mnohonárodnostnom a konfesionálne diverzifikovanom Uhorsku celé stáročia zohrávala významnú rolu predovšetkým v úradných a verejných písomnostiach a bola jazykom vzdelancov napojených na európsku krestanskú kultúru (Dorula 2015, 10). Výskum paralelných latinsko-cirkevnoslovanských textov z prostredia Mukačevského biskupstva preto svedčí o používaní latinskej terminológie ako neoddelitelnej súčasti konfesionálnej písomnej kultúry v prostredí cirkvi byzantsko-slovanského obradu pod Karpatmi (Strýčková 2019, 134-144). Administratívnoprávna pisárska prax v prostredí mukačevskej byzantsko-slovanskej tradície obsahovala totiž také prevzatia z latinskej terminológie, ktorá sa prostredníctvom všeobecnej úradníckej pisárskej praxe udomácnila nielen $\mathrm{v}$ administratívnom a právnom systéme uhorskej spoločnosti, ale stala sa neoddelitelnou súčastou bežnej komunikácie aj v ludovom jazyku. Patria k nim napríklad lexémy, ktoré uvádzame v štúdii k vydanému latinsko-cyrilskému rukopisu štatútov Manuela Michala Olšavského z rokov 1752 1758. V celom spomínanom rukopise je množstvo ustálenej latinskej terminológie (pozri k tomu bližšie Zubko - Žeňuch 2019, 5-100).

V jednotlivých národných spoločenstvách Slovanov, kde sa uplatňuje byzantský obrad, liturgická cirkevná slovančina sa v ústnej podobe realizuje ako konkrétny slovanský jazykový variant či redakcia. Liturgickú podobu, redakciu liturgického cirkevnoslovanského jazyka primárne určuje výslovnostná (ortoepická) zložka. Jej východiskom je systémová zvuková osnova konkrétneho slovanského jazyka. V ústnom prejave (pri deklamácii či speve liturgických modlitieb a hymnov) sa tak cirkevná slovančina naplno prispôsobuje osobitostiam zvukového systému konkrétneho slovanského jazyka. Hovoríme preto o vplyve národného jazykového prostredia a povedomia používatel'ov na liturgickú podobu cirkevnoslovanského jazyka. Súvisí s tým vznik konkrétnej národnej jazykovej redakcie liturgickej cirkevnej slovančiny, ktorá sa realizuje v súlade s konkrétnym jazykovým prostredím, napríklad bulharským, ruským či srbským. Na redakcie cirkevnoslovanského liturgického jazyka však vplývajú aj dalšie skutočnosti, ktoré súvisia s miestnymi 
nárečovými pomermi. Tieto osobitosti formujú a podmieňujú vznik d’alších miestnych, lokálnych typov či podtypov jednotlivých redakcií liturgickej cirkevnej slovančiny. Takýmto podtypom (subredakciou) je napríklad haličsko-ukrajinský typ cirkevnej slovančiny či podkarpatsko-ruský alebo východoslovenský variant ${ }^{9}$ ukrajinskej redakcie cirkevnej slovančiny.

Národná redakcia či variant príslušnej jazykovej redakcie (teda zvuková podoba) liturgickej cirkevnej slovančiny sa najčastejšie uplatňuje pri slávení jednotlivých bohoslužobných obradov cirkvi ako živý komunikačný nástroj človeka s Bohom a v biblických a liturgických textoch. Biblické a bohoslužobné písomné pamiatky sa podnes zachovali v pestrej palete redakcií. Ich primárnym zdrojom či východiskom je však taká písomná podoba, ktorá vychádza z takej cirkevnoslovanskej jazykovej osnovy, ktorú dokladujú a opisujú staroslovienske a cirkevnoslovanské gramatiky najstaršieho slovanského literárneho jazyka (Suprun - Moldovan 2005, 29-69; Pletneva - Kravetskiy 2006; Kurz 1969; Stanislav 1978 a 1987). Starosloviensky a cirkevnoslovanský jazyk tak možno pokladat za najstarší kultivovaný slovanský knižný jazyk, jazyk najstaršej písomnej kultúry, v ktorom sa do dnešných dní petrifikovali aj slovanské preklady biblických kníh spolu s celou produkciou bohoslužobných a liturgických textov, kánonov a pravidiel cirkevného života (Žeňuch - Belyakova - Naydenova - Zubko - Marinčák 2018).

Byzantsko-slovanská tradícia spolu s cyrilskými písomnostami predstavuje jedinečnú súčast’ slovenskej kultúry (Žeňuch 2002, 26-27 a Žeňuch 2015, 37). Ved' sa v nej odráža nielen starobylé dedičstvo velkomoravskej cirkvi s byzantsko-slovanskou duchovnostou a obradmi, ktoré našlo vhodné podmienky na svoje pokračovanie predovšetkým medzi južnými a východnými Slovanmi, kde sa naplno uplatnilo a kde aj vznikla bohatá slovanská písomná kultúra. Jej presahy a vplyvy vd’aka kontaktom s južnoslovanským a východoslovanským prostredím (Avenarius 1992) a jej oživenie či posilnenie prostredníctvom pastierskej kolonizácie spôsobili rozvoj byzantskej duchovnej a konfesionálnej identity aj v slovenskom prostredí. O spätosti byzantského obradu slovanskej tradície a o jej spojení prostredníctvom písomných prameňov so slovenským kultúrnym horizontom svedčia práve kultúrnohistorické reálie a jazykové doklady, ktoré sú evidentne zaznamenané v živej ludovej tradícii i v textoch rozličných cyrilikou zapísaných písomností. Vel'kú čast rukopisnej tradície tvoria nielen liturgické texty (liturgikony, triodiony, miney, trebníky, žaltáre, apoštoláre, evanjeliáre a dalšie), ktoré obsahujú predpísané bohoslužobné modlitby a hymny v liturgickej cirkevnej slovančine. Práve tieto štandardizované texty sú určené na bohoslužobné slávenie a v nemennej jazykovej forme pretrvávajú stáročia od čias velkomoravskej cirkvi. Okrem nich v tomto prostredí vznikali a používali sa rukopisné zbierky výkladov a homílií, apologetické spisy, pre organizáciu cirkevného života sú dôležité pravidlá svetského a cirkevného života, ktoré slúžili ako návod na každodenný život. Osobitnú skupinu rukopisných prameňov tvoria výklady a ponaučenia, apokryfy, legendy, povesti i súbory príbehov o živote svätých a o pôvode sviatkov. Zvyčajne ide o odpisy zo starších predlôh, alebo sú to štylizácie a preklady textov z latinských a gréckych originálov. V jazyku cyrilských rukopisov staršieho obdobia z regiónu pod Karpatmi sa objavujú prvky prevzaté nielen z východoslovanskej redakcie cirkevnej slovančiny, ale obsahuje aj stopy bulharskej pisárskej školy. K takýmto textom, v ktorých sa objavuje vplyv východoslovanskej i bulharskej pisárskej tradície, patrí napríklad Baškovský evanjeliár z 15. storočia (Žeňuch - Vasil' 2003, 357-359), Nižnotvarožský evanjeliár zo 16. storočia, Humenský rukopisný zborník výkladov k evanjeliovým perikopám zo 17. storočia (Žeňuch 2013b, 432-433), Ladomirovské výklady k perikopám zo 17. storočia (Pan'kevich 1923, 93-107), Skotarské poučitelné evanjelium zo 16. storočia

9 Pri bohoslužobných obradoch veriaci cirkvi byzantského obradu na Slovensku v závislosti od svojej jazykovo-etnickej identity používajú východoslovenský alebo rusínsky variant ukrajinskej redakcie cirkevnej slovančiny (pozri k tomu napríklad štúdie Žeňuch 1998, 649-662; Žeňuch 2000, 231-274; Žeňuch 2008, 97-107; Žeňuch 2017, 21-36). 
(Kochish 1997), Uglianske rukopisy zo 17. storočia (Šašerina 2019), Terebliansky Prológ (Yavorskiy 1931, 104-109) či Užhorodský Pseudozonar zo 16. storočia (Žeňuch - Belyakova - Naydenova Zubko - Marinčák 2018), ale tiež Hanigovský rukopis (Šima 2007), Gerlachovský apoštolár s výkladom perikop zo 16. storočia (Slivka - Isaevich - Maslovskiy 1989, 28) či Užhorodský poloustav zo 14. storočia s pravidlami mníšskeho života (Kolessa 1925), Mukačevský žaltár (Sokolov 1883; Sopko 2015, 78-81) a mnoho dalších rukopisných prameňov, o ktorých sa tu dalej už nebudeme zmieňovat. Cyrilské texty sa prepisovali, odpisovali alebo vznikali ako kompiláty z viacerých zdrojov. Ponúkali nielen poučné a didaktické texty, ale utvárali obraz o tradičnej miestnej kultúre a vzdelanosti. Sú charakteristické tým, že obsahujú také jazykové prvky, ktoré do písaných cyrilských textov prenikali z miestnych nárečí.

Súbor tu vymenovaných i d’alších cyrilských rukopisných prameňov svedčí nielen o prítomnosti byzantsko-slovanskej cirkevnej tradície, ale aj o živej pisárskej tradícii, ktorá disponovala protografmi (predlohami), ktoré podnes tvoria základ duchovnej tradície a kultúrneho kontinua byzantsko-slovanskej tradície aj v priestore pod Karpatmi.

\section{REFERENCES}

Avenarius, Alexander. 1992. Byzantská kultúra v slovanskom prostredí v VI. - XII. storočí: k problému recepcie a transformácie. Bratislava.

Afanas'va, Tat'yana. 2012. Литургическая терминология в славянских служебниках XIII $\mathrm{XV}$ вв.: эволюция литературной нормы и церковного узуса [Liturgicheskaya terminologiya v slavyanskikh sluzhebnikakh XIII-XV vv.: evolyuciya literaturnoy normy i tserkovnogo uzusa]. In Русский язык в научном освещении [Russkiy yazyk v nauchnom osveshchenii] 23/1, 250-266.

Bugan, Bystrík. 2009. Mojžiš Uhorský (Mojsej Uhrin) a jeho bratia v kontexte slovenských dejín. In Historický zborník 19/2, 137-146.

Czambel, Samuel. 1906. Slovenská reč a jej miesto v rodine slovanských jazykov. Turčiansky Sv. Martin.

Charskiy, Vyacheslav. 2011. Русинский язык Сербии и Хорватии в свете языковых контактов. Лингвогенетический аспект [Rusinskiy yazyk Serbii i Khorvatii v svete yazykovykh kontaktov. Lingvogeneticheskiy aspekt]. Shchelkovo.

Chuchka, Pavlo. 1993. Етнонім русин та руснак і їх деривати в південнокарпатських говорах [Etnonym rusyn ta rusnak i ikh deryvaty v pivdennokarpatskykh govorakh]. In Наукові записки [Naukovi zapysky] 18, 121-128.

Dorula, Ján. 1993. Tri kapitoly zo života slov. Bratislava.

Dorula, Ján. 2015. Slováci medzi starými susedmi (môžu byt’ aj Slováci starí?). Bratislava.

Gerovskiy, Yuriy. 1957. Южно-карпатское название руснак и его западнославянские соответствия [Yuzhno-karpatskoe nazvanie rusnak i ego zapadnoslavyanskie sootvetstviya]. In Československá rusistika 2, 429-442.

Húsek, Ján. 1925. Národopisná hranice mezi Slováky a Karpatorusy s mapou a obrázky. Bratislava. Jáger, Róbert. 2018. Časové vymedzenie vzniku vel'komoravského nomokánona [Time Determination of the Great Moravian Nomocanon]. In Konštantínove listy [Constantine's Letters] 11/2, 67-77.

Jáger, Róbert. 2019. Legal and social status of the church in Great Moravia. In Journal on European History of Law 10/2, 115-120. 
Yavorskiy, Yuliyan. 1931. Новыя рукописныя находки въ области старинной карпаторусской письменности XVI - XVIII въковъ [Novyya rukopisnyya nakhodki v oblasti starinnoy karpatorusskoy pis'mennosti XVI - XVIII věkov]. Praha.

Kochish, Mihay. 1997. Скотарське учительне євангеліє - український гоміліар 1588 року [Skotars'ke uchitel'ne yevanheliye]. Szombathely.

Kolessa, Oleksander. 1925. Ужгородський „Полуставъ“, у пергаміновій рукописі XIV в. [Uzhhorods'kyy "Polustav", u pergaminoviy rukopysi XIV v.]. In Записки Наукового тов. Шевченка [Zapysky Naukovoho tov. Shevchenka]. tom 141-143. Lviv.

Krivko, Roman. 2015. Очерки языка древних церковнославянских рукописей [Ocherki yazyka drevnikh tserkovnoslavyanskikh rukopisey]. Moskva.

Kurz, Josef. 1969. Učebnice jazyka staroslověnského. Praha.

Labanc, Peter. 2017. Otázka existencie východného rítu v 13. a 14. storočí na Spiši. [The Question of the Existence of Eastern Rite in Spiš During 13th and 14th Century]. In Konštantínove listy [Constantine's Letters]10/1, 198-210.

Maksimovich, Kirill. 2007. Паннонские юридические памятники в древнерусской книжности (диссертация на соискание ученой степени доктора филологических наук) [Pannonskie yuridicheskie pamyatniki v drevnerusskoy knizhnosti (dissertaciya na soiskanie uchenoy stepeni doktora filologicheskikh nauk)]. Moscow.

Marek, Miloš. 2006. Cudzie etniká na stredovekom Slovensku. Martin.

Mareš, Francis Wenceslas. 1979. An Anthology of Church Slavonic Texts of Western (Czech) Origin: with an Outline of Czech-Church Slavonic Literature and with a Selected Bibliography. München.

Neumann, Martin. 2014. Vypovedacia schopnost’ stredovekých kalendárií na príklade Spišského misála. In Historia nova 8, 8-32. https:/fphil.uniba.sk/fileadmin/fif/katedry_pracoviska/ ksd/h/Hino8b.pdf.

Olteanu, Pandele. 1947. Rumunská kultúra a slovanstvo. Bratislava.

Pan'kevich, Ivan. 1923. Ладомироิвске Учительне Евангеліе [Ladomirôvske Uchitel'ne Evanhelie]. In Науковый зборник товариства Просвъта в Ужгородъ [Naukovyy zbornyk tovarystva Prosvěta v Uzhhorodě], 93-107.

Pauliny, Eugen. 1961. Začiatky kultúrneho jazyka slovenskej národnosti. In Jazykovedné štúdie VI. Bratislava, 5-39.

Pauliny, Eugen. 1965. Západoslovanské výpožičky v staromadarskej lexike. In Ratkoš, Peter (ed.). O počiatkoch slovenských dejín. Bratislava, 190-203.

Pletneva, Aleksandra - Kravetskiy, Aleksandr. 2006. Церковнославянский язык [Tserkovnoslavyanskiy yazyk]. Moskva.

Plišková, Anna. 2009. Language and National Identity: Rusyns South of Carpathians. New York.

Považan, Michal. 2014. Trestné právo na Slovensku do rozpadu Velkej Moravy. In Historia et Theoria Iuris 6/1, 18-25.

Slivka, Yuriy - Isaevich, Yaroslav - Maslovskiy, Vitaliy. 1989. Украинские Карпаты. История. [Ukrainskie Karpaty. Istoriya]. Kyiv.

Sokolov, Ivan. 1883. Мукачевская Псалтырь XV въка [Mukachevskaya Psaltyr' XV věka]. In Сборникъ статей по славяновъдънію [Sbornik statey po slavyanověděniyu]. Saint Petersburg.

Sopko, Odarka. 2015. Структура рукопису «Мукачівського псалтиря» XIV - XV століття: інтерпретація шрифтової форми [Struktura rukopysu "Mukachivs'koho psaltyrya" XIV $\mathrm{XV}$ stolittya: interpretatsiya shriftovoyi formy]. In Вісник Закарпатського художнього інституту [Visnyk Zakarpats'koho khudozhnoho instytutu]. Volume 7. Uzhhorod, 78-81. 
Suprun, Adam - Moldovan, Aleksandr. 2005. Старославянский и церковнославянский язык [Staroslavyanskiy i tserkovnoslavyanskiy yazyk]. In Языки мира. Славянские языки [Yazyki mira. Slavyanskie yazyki]. Moscow, 26-69.

Stanislav, Ján. 1950. Zo života slov a našich predkov. Bratislava.

Stanislav, Ján. 1978. Starosloviensky jazyk. 1. Velká Morava a Panónia. Kultúrny jazyk a písomníctvo. Konštantín Filozof, Metod a Kliment sloviensky. Fonetika. Bratislava.

Stanislav, Ján. 1987. Starosloviensky jazyk. 2. Morfológia. Bratislava.

Strýčková, Mária. 2019. Latinsko-cirkevnoslovanský glosár k Bazilovičovmu liturgickému komentáru. In Žeňuch, P. a kol. Pohlady do problematiky cyrilskej písomnej tradície na Slovensku. Bratislava, 134-144.

Šašerina, Svetlana. 2019. Dva uglianske rukopisy ponaučení a exempiel zo 17. storočia / Две углянские рукописи поучений и притч XVII века [Dve uglyanskie rukopisi poucheniy i pritch XVII veka]. Monumenta Byzantino-Slavica et Latina Slovaciae. Vol. VI. Bratislava.

Šima, Pavel. 2007. Hanigovské evangelium. Trnava.

Šoltés, Peter - Žeňuch, Peter. 2001. Sociálne a spoločenské postavenie gréckokatolíkov na východnom Slovensku a v Podkarpatskej Rusi v 18. storočí. I. In Slavica Slovaca 36/2, 133-146.

Šoltés, Peter - Žeňuch, Peter. 2002. Sociálne a spoločenské postavenie gréckokatolíkov na východnom Slovensku a v Podkarpatskej Rusi v 18. storočí. II. In Slavica Slovaca 37/1, 37-47.

Šoltés, Peter. 2009. Tri jazyky, štyri konfesie. Etnická a konfesionálna pluralita na Zemplíne, Spiši a v Šariši. Bratislava.

Vaillant, André. 1960. Славянское название селезенки [Slavianskoe nazvanje selezenki]. In Вопросы языкознания [Voprosy jazykoznanija] IX/6, 66-67.

Vašica, Josef. 1996. Literární památky epochy velkomoravské. Praha.

Wilšinská, Lubomíra. 2019. O byzantsko-slovanskej monastickej tradícii na príklade latinskej literárnej tvorby Joannikija Juraja Baziloviča OSBM (1742 - 1821). In Žeňuch, Peter et al. Pohlady do problematiky cyrilskej písomnej tradície na Slovensku. Bratislava, 125-133.

Zavarský, Svorad. 2019. K latinským pamiatkam spätým so zjednotenou cirkvou byzantsko-slovanského obradu na Slovensku (17. a 18. storočie) - prehlad výskumu. In Žeňuch, Peter et al. Pohlady do problematiky cyrilskej písomnej tradície na Slovensku. Bratislava, 113-124.

Zubko, Peter. 2016. O dokumente Užhorodskej únie z 24. apríla 1646. In Slavica Slovaca 51/1, 3-9.

Zubko, Peter. 2019. K problematike latinsko-byzantských vztahov. In Žeňuch, Peter et al. Pohlady do problematiky cyrilskej písomnej tradície na Slovensku. Bratislava, 30-45.

Zubko, Peter - Žeňuch, Peter. 2019. Diecézne štatúty Michala Manuela Olšavského z rokov 1752 1758. In Slavica Slovaca 54/3-4 (supplementum), 5-100.

Žeňuch, Peter - Vasil,' Cyril. 2003. Cyrillic Manuscripts from East Slovakia. Slovak Greek Catholics: Defining Factors and Historical Milieu / Cyrilské rukopisy z východného Slovenska. Slovenskí gréckokatolíci, vztahy a súvislosti. Monumenta Byzantino-Slavica et Latina Slovaciae. Vol. I. Roma - Bratislava - Košice.

Žeňuch, Peter. 2000. Cirkevná slovančina v bohoslužobnej praxi Slovákov byzantsko-slovanského obradu na východnom Slovensku. In Dorula, Ján (ed.). Slovensko-rusínsko-ukrajinské vztahy od obrodenia po súčasnost. Bratislava, 231-274.

Žeňuch, Peter. 2002. Medzi Východom a Západom. Bratislava.

Žeňuch, Peter. 2008. Patria cyrilské paraliturgické piesne do kontextu slovenskej kultúry? In Slavica Slovaca 43/2, 97-107.

Žeňuch, Peter. 2011. Z výskumu pomedzného užského nárečového areálu (na príklade nárečia obce Kaluža). In Slavica Slovaca 46/1, 51-62. 
Žeňuch, Peter. 2013a. Slovensko-slovanské dimenzie duchovnej kultúry Slovenska. In Žeňuch, Peter - Uzeňova, Elena - Žeňuchová, Katarína (eds.). Jazyk a kultúra na Slovensku v slovanských a neslovanských súvislostiach. Bratislava, 11-30.

Žeňuch, Peter. 2013b. Источники византийско-славянской традиции и культуры в Словакии [Istochniki vizantiysko-slavyanskoy tradicii i kul'tury v Slovakii] / Pramene k byzantsko-slovanskej tradícii a kultúre na Slovensku. Monumenta byzantino-slavica et latina Slovaciae IV. Bratislava - Roma.

Žeňuch, Peter. 2014. Kultúrne stereotypy v byzantsko-slovanskom konfesionálnom prostredí na Slovensku. In Slavica Slovaca 49/2, 121-137.

Žeňuch, Peter. 2015. K dejinám cyrilskej písomnej kultúry na Slovensku. Nitra.

Žeňuch, Peter. 2016. Andrej Deško a Bohuš Nosák-Nezabudov o kultúrnych stereotypoch na východnom Slovensku a v Podkarpatskej Rusi v 40. rokoch 19. storočia. In Slavica Slovaca 51/1, 10-32.

Žeňuch, Peter. 2017. Cirkevná slovančina slovenských veriacich byzantského obradu. In Žeňuch, Peter - Zubko, Peter - Vašíčková, Svetlana (eds.). Liturgické jazyky v duchovnej kultúre Slovanov. Bratislava, 21-36.

Žeňuch, Peter. 2018. Vojvodinskí Rusnáci a slovenskí rusnáci: Jazyková, konfesionálna a etnická identita v komparácii. In Slavica Slovaca 53/3-4 (supplementum), 75-85.

Žeňuch, Peter - Belyakova, Elena - Naydenova, Desislava - Zubko, Peter - Marinčák, Šimon. 2018. Užhorodský rukopisný Pseudozonar. Pravidlá mníšskeho a svetského života z prelomu 16.-17. storočia / Ужгородский рукописный Псевдозонар. Правила монашеской и светской жизни рубежа XVI-XVII вв. Monumenta Byzantino-Slavica et Latina Slovaciae. Vol. V. Bratislava - Moscow - Sofia - Košice.

Žeňuch, Peter. 2019. Cyrilské písomníctvo na Slovensku v kontexte aktuálnych výskumov. In Žeňuch, Peter et al. Pohlady do problematiky cyrilskej písomnej tradície na Slovensku. Bratislava, 11-30.

SUMMARY: THE BYZANTINE-SLAVIC TRADITION IN THE OLDER PERIOD OF SLOVAK CULTURE DEVELOPMENT. The paper is devoted to the results of a Slavic, systematic multi-year scientific research of the linguistic-cultural identity of Slovak Byzantine rite believers. It explains some aspects of the functioning of this culture in the context of written sources and selected language phenomena. Special mention is made of the name of the believers of the Byzantine rite in Slovakia in the context of ethnic-cultural identification and the contribution of the Slovaks in the formation of the cultural phenomenon of the Byzantine-Slavic tradition under the Carpathians. It turns out that Byzantine-Slavic tradition represents the unique part of the Slovak culture. It reflects the antique legacy of the Greater Moravian Church with Byzantine-Slavic spirituality and rituals that found adequate conditions for its continuation not merely among southern and eastern Slavs, where it was fully applied and allowed rise of rich Slavic written culture. Cultural and historical realities and linguistic documents that are noticeably recorded in the living popular tradition, as well as in the various texts written in Cyrillic script, prove to the adherence of Byzantine rite to the Slovak cultural milieu. This tradition forms a base of living spiritual and cultural continuum of the Byzantine-Slavic tradition in Slovakia. 
Prof. PhDr. Peter Žeňuch, DrSc.

Department of Slovak Language and Literature

The Institute of Philological Studies

Faculty of Education

Comenius university in Bratislava

Šoltésovej 4

81108 Bratislava

Slovakia

zenuch1@uniba.sk 